\title{
Use of a Single Team-Based Written Project to Address Multiple Objectives and Outcomes for a Biomedical Engineering Program
}

\author{
Susan M. Blanchard and Marian G. McCord \\ North Carolina State University
}

I. Introduction

Members of the Biomedical Engineering faculty at NC State have developed a set of student learning outcomes based on broader programmatic objectives and ABET criteria. ${ }^{1}$ Course learning outcomes are being mapped to program outcomes, and assignments that provide evidence of student learning are being collected and reviewed. Assignments that are identified for collection and analysis are frequently semester-long, team-based projects that address many outcomes and allow students to demonstrate proficiency in several areas. One such assignment is the team-based written term project in BAE 382 (formerly BAE 465): Biomedical Engineering Applications. The projects represent chapters in an electronic textbook that has been contributed to by students since the fall of 1994. ${ }^{2,3}$ Projects developed over the last five years can be viewed at http://www.bae.ncsu.edu/research/blanchard/www/465/textbook/projects.html. Each chapter is based on one of the body's systems or senses or a specialized area of biomedical engineering.

Students writing about specialized areas in biomedical engineering were asked to describe: (1) The medical aspects of the biomedical engineering problem and why it is (or was) important; (2) The patient population, i.e. who needs this device or measurement and why; (3) The history of the development of engineering solutions, e.g. pre-computer solutions. What was tried and what worked? When was the product or device first invented? When did it become available for patient use? (4) Physiological signals that are (were) measured. What type of transducers and biosensors were used? What were the design considerations that were important? How was the system calibrated? (5) Patient safety issues; (6) Any failures; (7) Recent engineering solutions to the health care problem; (8) How the availability of computers affected the way the device was built or how signals were measured and processed; (9) Other technological innovations that affected this specialized area; and (10) Improvements that are needed in the future. Students writing about a body system were asked to describe much of the same material in addition to the anatomy, physiology, function, and medical relevance of their topic.

These term projects are being used to assess the following objectives and outcomes (Figure 1) for what graduates of the B.S. in Biomedical Engineering should be able to do, as well as certain ABET Criteria (given in parentheses):

- Objective 1, Outcome b: Identify contemporary clinical issues and be able to discuss potential biomedical engineering solutions. (3a, 3e, 3j, 3k, 8)

- Objective 2, Outcome b: Prepare effective written materials. (3g)

- Objective 2, Outcome d: Work effectively in multidisciplinary teams to complete projects. (3d) 
- Objective 3, Outcome b: Articulate, identify, and evaluate contemporary ethical issues in biomedical engineering and their impact on society. (3f, $3 \mathrm{~h}, 3 \mathrm{j}$ )

- Objective 4, Outcome a: Assess, evaluate, and reference peer-reviewed technical literature. $(3 \mathrm{~g}, 3 \mathrm{i})$

\section{Student Teams}

Students were placed in 4-person multidisciplinary teams. Since all of the students in BAE 382 are biomedical engineering students who are following the same curriculum, "multidisciplinary" was defined in terms of gender, ethnicity, and learning styles. Students were asked to determine their learning styles by completing the Index of Learning Styles (ILS) questionnaire, available from http://www.ncsu.edu/felder-public/ILSdir/ilsweb.html, and submitting their scores to the course instructor. ${ }^{4}$ Possible ILS scores are between -11 and +11 with the minus scores being used to designate active, sensing, visual, and sequential learners whereas the plus scores designate reflective, intuitive, verbal, and global learners. ${ }^{5}$ All teams had at least one category in which team members differed by at least 12 points, e.g. -9 to 3 on the sequential to global scale or -5 to 7 on the visual to verbal scale. Five of the twelve teams had scores that differed by 16 points in at least one category. All teams except for one, which had an 8-point spread, had a second category that differed by at least ten points. All teams had both male and female members, except for one team whose sole male member was called to active duty in the Air National Guard in March. Ten of the twelve teams had members who represented ethnic minorities. Team members were also assigned so that the mean GPA for each team, which ranged from 3.30 to 3.78, was as close as possible to the mean GPA of 3.32 for the class.

\section{Assessment Rubrics}

Rubrics have been developed to determine the level of achievement of the five different outcomes that are being assessed through the BAE 382 project. Table I describes the highest level of achievement for each outcome. The assessment results for the twelve projects developed in spring 2003 will be presented and will be compared to the assessment results for five projects produced in 2002, i.e. before assessing specific outcomes and objectives for the B.S. in Biomedical Engineering was linked to the BAE 382 projects. 
Table I: BAE 382 Project Evaluation Rubric

\begin{tabular}{|c|c|}
\hline Objective.outcome & $\begin{array}{r}\text { Highest Level of Achievement (Complete) } \\
\end{array}$ \\
\hline $\begin{array}{l}\text { 1.b. Identify } \\
\text { contemporary clinical } \\
\text { issues and be able to } \\
\text { discuss potential } \\
\text { biomedical } \\
\text { engineering solutions. }\end{array}$ & $\begin{array}{l}\text { The project identifies and clearly articulates one or more opportunities } \\
\text { for biomedical engineering solutions of clinical problems. The identified } \\
\text { problem is specific and focused. Solutions are assessed in terms of } \\
\text { timeliness, i.e. urgency and prevalence of the problem. Solutions are } \\
\text { addressed in terms of available technology. The efficacy of current and } \\
\text { previous solutions is addressed. The impact on society of proposed } \\
\text { solutions is discussed. Statistical data from referenced papers is } \\
\text { provided to substantiate the impact on society. }\end{array}$ \\
\hline $\begin{array}{l}\text { 2.b. Prepare effective } \\
\text { written materials. }\end{array}$ & $\begin{array}{l}\text { The format is appropriate, including a clear differentiation between } \\
\text { levels and the use of scientific headings (e.g., Introduction, References, } \\
\text { etc.), with logical and consistent organization. Hyperlinks are } \\
\text { thoughtfully chosen, relevant, and effective. Computer-generated } \\
\text { graphics/images are professional quality and enhance and illustrate ideas } \\
\text { and concepts. Color is used appropriately to aid in navigation of the } \\
\text { website. The text represents a synthesis of information derived from a } \\
\text { number of appropriate reference sources, including books and journal } \\
\text { articles, and includes smooth transitions between paragraphs and } \\
\text { sections. The ideas are presented in language appropriate for a lay } \\
\text { audience. All hyperlinks are appropriately referenced so that there are } \\
\text { no copyright infringements. }\end{array}$ \\
\hline $\begin{array}{l}\text { 2.d. Work effectively } \\
\text { in multidisciplinary } \\
\text { teams to complete } \\
\text { projects. }\end{array}$ & $\begin{array}{l}\text { Team members have a very clear understanding of the complementary } \\
\text { nature of their individual contributions. Individual personality traits, } \\
\text { learning styles, and experiences that may affect communication have } \\
\text { been addressed, and the value of diversity is appreciated. Team } \\
\text { communication is regular and documented. Individual contributions are } \\
\text { meaningful as assessed by peers. The team makes decisions by } \\
\text { consensus. Conflicts are effectively managed and resolved. }\end{array}$ \\
\hline $\begin{array}{l}\text { 3.b. Articulate, } \\
\text { identify, and evaluate } \\
\text { contemporary ethical } \\
\text { issues in biomedical } \\
\text { engineering and their } \\
\text { impact on society. }\end{array}$ & $\begin{array}{l}\text { The project identifies and discusses all patient safety and ethical issues } \\
\text { involved in proposed or established biomedical engineering solutions. } \\
\text { The project discusses failures that occurred during the development of } \\
\text { engineering solutions. The project addresses other ethical issues unique } \\
\text { to the topic. The discussion addresses the complexity of issues } \\
\text { including an analysis of the cost/benefit of proposed solutions. }\end{array}$ \\
\hline $\begin{array}{l}\text { 4.a. Assess, evaluate, } \\
\text { and reference peer- } \\
\text { reviewed technical } \\
\text { literature. }\end{array}$ & $\begin{array}{l}\text { Referenced data is evaluated critically and cited appropriately. Students } \\
\text { are able to discriminate between different genres of published material, } \\
\text { e.g. peer-reviewed publications, web pages, etc. }\end{array}$ \\
\hline
\end{tabular}




\section{REFERENCES}

1. McCord, M. G., Blanchard, S. M., Mente, P. L., Nagle, H. T., and Spurlin, J. E. "Outcomes Based Curriculum Development in a New and Emerging Biomedical Engineering Program," Proceedings of the 2003 American Society for Engineering Education Annual Conference \& Exposition

2. Blanchard, S. M. and Carter, M. P. Helping biomedical engineering students develop Internet literacy. Int. J. Engng. Ed., vol. 15, pp. 270-275, 1999.

3. Blanchard, S. M. and Carter, M. P. Writing for the web: Student authors and authorities. Paper presented at $30^{\text {th }}$ ASEE/IEEE Frontiers in Education Conference, Paper F2G-6, Kansas City, MO, 2000.

4. Soloman, B. A. and Felder, R. M. Index of Learning Styles Questionnaire. http://www.ncsu.edu/felderpublic/ILSdir/ilsweb.html.

5. Felder R. M. and Soloman, B. A. Learning styles and strategies. http://www.ncsu.edu/felderpublic/ILSdir/styles.htm.

SUSAN M. BLANCHARD, Ph.D.

Dr. Blanchard received the A.B. in Biology from Oberlin College in 1968 and the M.S. (1980) and Ph.D. (1982) degrees in Biomedical Engineering from Duke University. She is currently a Professor in the Department of Biomedical Engineering and the Department of Biological and Agricultural Engineering at North Carolina State University, a Senior Member of the Biomedical Engineering Society, and a Fellow of AIMBE and the IEEE.

MARIAN G. McCORD, Ph.D.

Marian G. McCord received a Sc.B. in Biomedical Engineering from Brown University in 1985, an M.S. in Bioengineering at Clemson University in 1989, and a Ph.D. in Textiles and Polymer Science from Clemson University in 1994. She is currently an Associate Professor in the Department of Biomedical Engineering and the Department of Textile Engineering, Chemistry and Science at North Carolina State University. 


\section{Figure 1: Program Educational Objectives, Outcomes, and Assessment Methods Using the Team Projects from BAE 382}

1. To educate students to be successful in Biomedical Engin eering by emphasizing engi neering and biology as related to basic medical sciences and human h ealth.

After completing the B.S. in Biomedical Engineerin g, students will be able to:

b. Identify contemporary clinical issues and be able to discus s potential biomedical engin eering solutions. (3a, 3e, 3j, 3k, 8)

i. Written term projects from BAE 382 on selected conte mporary human health issues and relevant biomedical engineering solutions. Student understanding of the contemporary issue and its biomedical engineering solutions are assessed by faculty with a facultydesigned rubric. (Every semester th e course is taugh $\mathrm{t}$.)

2. To produce Biomedical Engin eers able to communicate effectively with diverse audiences and prepared to work in multidisciplinar y teams.

After completing the B.S. in Biomedical Engineerin g, students will be able to:

b. Prepare effective written materials. $(3 \mathrm{~g})$

i. Written term projects from BAE 382 on selected co ntemporary human health issues, which include biomedical engineering solutions. Student ability to write an effective project is assessed by faculty with a faculty-designed rubric. (Every semester the course is taught.)

d. Work effectively in multidiscipl inary teams to complete projects. (3d)

i. Students in BAE 382 are assigned to te ams that include members from both genders, from different eth nic backgrounds (when this is possible based on the composition of the class), and with different learning styles. A faculty-designed rubric is administered to all students in this course to determine how effectively their team functioned. (Every semester the course is taught.)

3. To develop in studen ts professional, eth ical, and societal responsibility in Biomedic al Eng ineering practices.

After completing the B.S. in Biomedical Engineerin g, students will be able to:

b. Articulate, iden tify, and evaluate contemporary e thical issues in biomedical engineering and their impact on society. (3f, 3h, 3j)

i. Written term projects from BAE 382 on selected co ntemporary human health issues, which include ethical issues. Student understanding of ethical issues is assessed by faculty $w$ ith a faculty-designed rubric. (Every semester the course is taught.)

4. To introduce students to adv ances in Biomedical Engineering practice and research an $d$ to instill in them a life-long thi rst for knowledge.

After completing the B.S. in Biomedical Engineering, student $\mathrm{s}$ will be able to:

a. Assess, evaluate, an d reference peer-review ed technical liter ature. $(3 \mathrm{~g}, 3 \mathrm{i})$

i. Reference section for written term projects on selected contemporary human health issues from BAE 382. Appropriateness of references that the students select to document their projects is assessed by faculty with a faculty-designed rubric. (Every semester the course is taught.) 